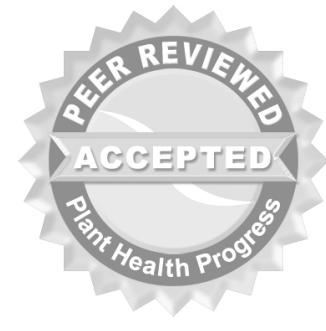

(c) 2010 Plant Management Network.

Accepted for publication 18 November 2009. Published 16 February 2010.

\title{
First Report of Two Curtoviruses in Spinach and Common Beet in Arizona
}

Claudia Nischwitz and Mary W. Olsen, School of Plant Sciences, The University of Arizona, Forbes 303, P.O. Box 210036, Tucson, AZ 85721

Corresponding author: Claudia Nischwitz. claudian@email.arizona.edu

Nischwitz, C., and Olsen, M. W. 2010. First report of two curtoviruses in spinach and common beet in Arizona. Online. Plant Health Progress doi: 10.1094/PHP-2010-0216-02BR.

Members of genus Curtovirus in family Geminiviridae have been reported in sugarbeets, chile pepper, cucurbits, tomato, bean, and various weeds in the southwestern United States $(2,4,5)$. Currently the genus consists of seven viruses. Beet curly top virus (BCTV), Beet severe curly top virus (BSCTV), and Beet mild curly top virus (BMCTV) have been found throughout the western United States in sugar beet, tomato, and pepper (5). Spinach curly top virus (SCTV) was reported from spinach in Texas (1). Horseradish curly top virus (HrCTV) was found in horseradish in California (3), and Pepper curly top virus (PCTV) and Pepper yellow dwarf virus (PYDV) were documented in chile peppers in New Mexico (4).

In winter 2008, $>90 \%$ of common beets (Beta vulgaris) in a commercial organic field in central Arizona were stunted, and leaves exhibited interveinal reddening and tip necrosis (Fig. 1). There were no signs of fungal or bacterial infections, and symptoms were atypical of BCTV-infected plants (6). Total DNA was extracted from leaves of stunted plants using the FastDNA Kit (MP Biomedical). PCR was run with PCR Taq Core (Qiagen) following manufacturers instructions using the primer pairs $\mathrm{CP} 4 \mathrm{f}$ and $\mathrm{CP} 6 \mathrm{r}$ (2) and BCTV 2repfI and BCTV 2reprI (4). The PCR products were visualized on $1.2 \%$ agarose gel. The resulting 576-bp and 723-bp bands, respectively, were extracted from the gel using QiaQuick Gel Extraction kit (Qiagen) and sequenced (The University of Arizona Genetics Core facility, Tucson, AZ). The sequences were compared to curtovirus sequences in the NCBI GenBank database using BLAST search. Both sequences matched closest with Pepper yellow dwarf virus (GenBank accession: EU921828) (97\% homology).

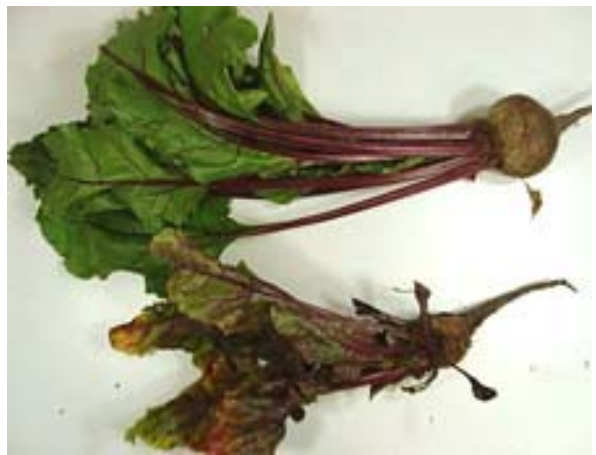

Fig. 1. Common beet plants that are healthy (top) or infected (bottom) with a curtovirus in Arizona.

In spring 2009, spinach (Spinacea oleracea) in southern Arizona showed severe curly top-like symptoms (Fig. 2). Numerous beet leafhoppers (Circulifer tenellus) were observed in the field. New growth was stunted and leaves were chlorotic and distorted. Many plants died, but there were no signs or successful 
isolations of oomycete or fungal pathogens that might cause similar symptoms. Samples submitted to a commercial diagnostic lab were negative for curtoviruses in a general curtovirus PCR screen. Total DNA was extracted and PCR conducted as described above. PCR with CP4f and CP6r primers was also negative. We designed new primers based on Spinach curly top virus sequences in GenBank for the rep region. These primers curtovirus 1 (5' - TCG GCC CAC TCT TGA ATA AC - '3) and curtovirus 2 ( 5 ' - ATG CCC GTT ACT TCG ATC TG '3) gave the expected 388-bp bands. The sequence of this band and a band obtained with BCTV 2repfI and BCTV 2reprI matched closest with Pepper curly top virus (GenBank accession: EF501977) (98\% homology).

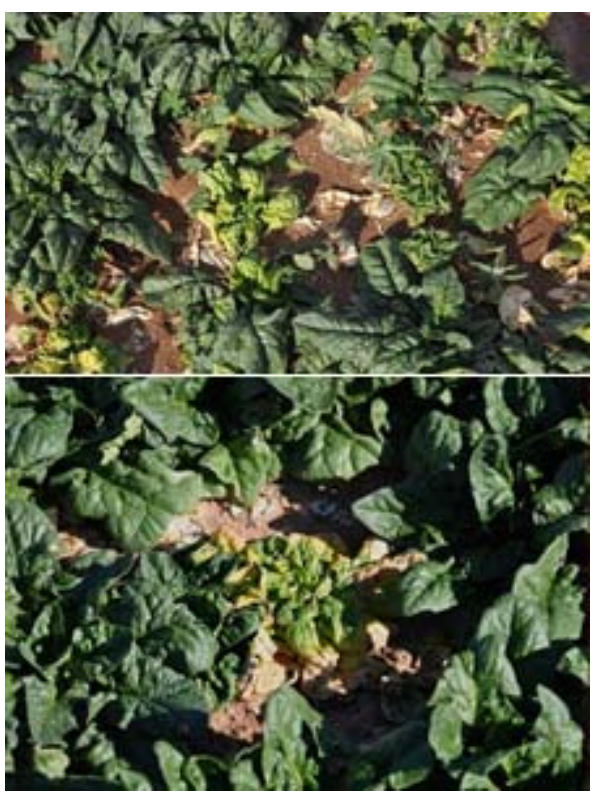

Fig. 2. Spinach plants infected with a curtovirus in an Arizona field.

Curtoviruses can cause severe financial losses for growers of leafy greens such as spinach and common beets. Research is currently underway to determine if these viruses are established in weeds and problematic in leafy greens crops throughout Arizona. It is likely that Pepper yellow dwarf virus and Pepper curly top virus are the infectious agents. However, we sequenced only part of the virus genome and due to recombination in curtoviruses the exact identity of the curtoviruses found in Arizona still needs to be confirmed. To our knowledge this is the first report of curtoviruses in common beet and in spinach in Arizona.

\section{Literature Cited}

1. Baliji, S., Black, M. C., French, R., Stenger, D. C., and Sunter, G. 2004. Spinach curly top virus: A newly described Curtovirus species from southwest Texas with incongruent gene phylogenies. Phytopathology 94:772-779.

2. Creamer, R., Hubble, H., and Lewis, A. 2005. Curtovirus infection of chile pepper in New Mexico. Plant Dis. 89:480-486.

3. Duffus, J . E., Milbrath, G. M., and Perry, R. 1982. Unique type of curly top virus and its relationship with horseradish brittle root. Plant Dis. 66:650-652.

4. Lam, N., Creamer, R., Rascon, J ., and Belfon, R. 2009. Characterization of a new curtovirus, Pepper yellow dwarf virus, from chile pepper and distribution in weed hosts in New Mexico. Arch. Virol. 154:429-436.

5. Strausbaugh, C. A., Wintermantel, W. M., Gillen, A. M., and Eujayl, I. A. 2008. Curly top survey in the Western United Stated. Phytopathology 98:1212-1217.

6. Wintermantel, W. M. 2009. Curly top. Pages 51-53 in: Compendium of Beet Diseases and Pests, 2nd Edn. R. M. Harveson, L. E. Hanson, and G. L. Hein, eds. American Phytopathological Society, St. Paul, MN. 